\title{
Fluxes of inorganic carbon from two forested catchments in the Appalachian Mountains
}

\author{
Fred Worrall, ${ }^{1 *}$ Wayne T. Swank ${ }^{2}$ and Tim Burt ${ }^{3}$ \\ ${ }^{1}$ Department of Geological Sciences, Science Laboratories, South Road, Durham DH1 3LE, UK \\ 2 Coweeta Hydrologic Laboratory, Southern Research Station, USDA Forest Service, Otto, NC, USA \\ ${ }^{3}$ Department of Geography, Science Laboratories, South Road, Durham DH1 3LE, UK
}

\begin{abstract}
:
This study uses long-term records of stream chemistry, discharge and air temperature from two neighbouring forested catchments in the southern Appalachians in order to calculate production of dissolved $\mathrm{CO}_{2}$ and dissolved inorganic carbon (DIC). One of the pair of catchments was clear-felled during the period of the study. The study shows that: (1) areal production rates of both dissolved $\mathrm{CO}_{2}$ and DIC are similar between the two catchments even during and immediately after the period of clear-felling; (2) flux of total inorganic carbon (dissolved $\mathrm{CO}_{2}+$ DIC) rises dramatically in response to a catchment-wide acidification event; (3) DIC and dissolved $\mathrm{CO}_{2}$ are dominantly released on the old water portion of the discharge and concentrations peak in the early autumn when flows in the study catchments are at their lowest; (4) total fluvial carbon flux from the clear-felled catchment is $11.6 \mathrm{t} \mathrm{km}^{-2} \mathrm{year}^{-1}$ and for the control catchment is $11.4 \mathrm{t} \mathrm{km}^{-2}$ year $^{-1}$. The total inorganic carbon flux represents $69 \%$ of the total fluvial carbon flux. The method presented in the study provides a useful way of estimating inorganic carbon flux from a catchment without detailed gas monitoring. The time series of dissolved $\mathrm{CO}_{2}$ at emergence to the stream can also be a proxy for the soil flux of $\mathrm{CO}_{2}$. Copyright $(9) 2005$ John Wiley \& Sons, Ltd.
\end{abstract}

\section{INTRODUCTION}

Forests represent approximately half the land-based carbon sink in the USA (Pacala et al., 2001). Goodale et al. (2002) estimate that US forests represent a carbon sink of $0.28 \mathrm{Pg} \mathrm{year}^{-1}$ for the year 1990-91. One important component of the fluxes of carbon through a forest ecosystem is the loss via streams; however, the total fluvial carbon flux from forest catchments has not been quantified. The flux via streams can be made of several components: particulate organic carbon (POC); dissolved organic carbon (DOC); dissolved inorganic carbon (DIC); dissolved $\mathrm{CO}_{2}$; and dissolved $\mathrm{CH}_{4}$. The particulate organic matter (POC) represents all physically present organic particles, e.g. leaves, as opposed to DOC, which represents the colloidal and truly dissolved organic matter dominated by humic and fluvic acids. The distinction between POC and DOC is defined operationally as that which passes through a filter of a given size, typically $0.45 \mu \mathrm{m}$.

Several studies of POC flux have been conducted in forest settings (e.g. Webster et al., 1999), as well as of DOC (e.g. Tate and Meyer, 1983). The DIC component represents the combination of carbonate, bicarbonate and carbonic acid, i.e. the result of the dissolution of $\mathrm{CO}_{2}$ into water, yet both $\mathrm{CO}_{2}$ and $\mathrm{CH}_{4}$ can be found in their truly dissolved state in natural waters. In their review of fluvial carbon fluxes, Hope et al. (1994) list many studies of DOC and POC in forested catchments, but report only two studies of DIC in forested catchments, only one of which (Hubbard Brook) is in the conterminous USA (Likens et al., 1977). Hope et al. (1994) list no studies of dissolved gases from forested catchments.

Subsequent research has provided some insights into the inorganic carbon and dissolved carbon gas fluxes from forested catchments. Jones and Mulholland (1998a) showed that dissolved $\mathrm{CO}_{2}$ represents an integration

\footnotetext{
* Correspondence to: Fred Worrall, Department of Geological Sciences, Science Laboratories, South Road, Durham DH1 3LE, UK.
}

E-mail: fred.worrall@durham.ac.uk 
of contributing processes (both in-stream or within the soil-groundwater system) and that if the contribution of in-stream processes can be estimated, then production from the soil-groundwater system can be calculated. Jones and Mulholland (1998b) compared dissolved $\mathrm{CH}_{4}$ and dissolved $\mathrm{CO}_{2}$ across a range of catchments and showed that geology, elevation and catchment size all affected the ratio of dissolved $\mathrm{CH}_{4}$ to dissolved $\mathrm{CO}_{2}$. As for dissolved $\mathrm{CH}_{4}$, Jones and Mulholland (1998c) showed that a stream in a forested catchment in the Applachians was supersaturated with $\mathrm{CH}_{4}$ with respect to the atmosphere by a factor of up to 41.4 .

The purpose of this study is to develop a long series of inorganic carbon and dissolved $\mathrm{CO}_{2}$ fluxes for a pair of forested catchments. The calculations will be made in comparison with other fluvial carbon fluxes calculated previously for the same catchments in order to assess the importance of these inorganic carbon loss pathways relative to organic carbon loss pathways. The fluxes of DIC and dissolved $\mathrm{CO}_{2}$ will be compared with the results of previous research on these study catchments that examined the controls on the composition of the discharge and balance of flowpaths contributing to the catchment discharge (Worrall et al., 2005). The catchments chosen for the study share a watershed, and they include a control catchment covered with mature hardwood and a catchment that was clear-felled in 1977.

\section{METHODOLOGY}

This study uses the long-term records of stream chemistry measured at the Coweeta Hydrologic Laboratory, North Carolina (Swank and Waide, 1986), for a pair of forested catchments to calculate the records of DIC and dissolved $\mathrm{CO}_{2}$. The approach combines and adapts the method of Neal et al. (1998) for calculating inorganic carbon speciation with the method of Jones and Mulholland (1998a) for estimating the proportion of dissolved $\mathrm{CO}_{2}$ derived from the soil-groundwater system.

\section{Study site}

Established in 1934, the Coweeta watersheds represent one of the longest continuous environmental studies presently available. The 2185 ha watershed is divided into two adjacent basins (Figure 1). The climate of the region is classified as marine, humid temperate (Swift et al., 1988). Mean annual precipitation varies from $1800 \mathrm{~mm}$ at low elevations in the basin to $2500 \mathrm{~mm}$ at the highest elevations, with March typically being the wettest month and snowfall making up less than $5 \%$ of the annual precipitation. Mean annual temperature is $12.6^{\circ} \mathrm{C}$ at the base station, with an average monthly low of $3.3^{\circ} \mathrm{C}$ in January and a high of $21.6^{\circ} \mathrm{C}$ in July. The geology of the basin is dominated by metamorphic formations, including schists, gneisses and metasandstones (Hatcher, 1988). Soils fall into two orders: immature inceptisols and older, mature ultisols. Steep faces at high elevations are covered by the umbric dystrochrepts of the Porter series; the remaining inceptisols are of the Chandler gravelly loam series. The ultisols comprise typic hapludults and humic hapludults. Typic hapludults cover the largest area of the basin and consist of the Coweeta-Evard gravelly loam and Fanin sandy loam series. Mixed mesophytic forests characterize the region, and the four major forest types of the basin have been described by Day et al. (1988).

This study focuses on a pair of catchments, nos 2 and 7. Control catchment (Shope Branch) is 12 ha in area with a maximum elevation of $1004 \mathrm{~m}$. Felled catchment (Big Hurricane) is 59 ha in size and reaches a maximum elevation of $1077 \mathrm{~m}$. The two catchments are adjacent and have similar southerly aspects (Figure 1). Catchment 7 was commercially clear-felled, cable logged in 1977 and allowed to regenerate naturally and hence is referred to as the felled catchment (Swank et al., 2001). As part of logging operations, three contour roadways were constructed traversing the catchment at $300 \mathrm{~m}$ intervals. Control catchment is one of the control catchments within the basin and has remained undisturbed since 1927, and is subsequently referred to as the control catchment. Stream gauging on both these catchments commenced in 1934. Stream water is sampled weekly. Samples are immediately refrigerated and analysed within 7 days. From February 1976, $\mathrm{K}^{+}, \mathrm{Na}^{+}, \mathrm{Ca}^{2+}, \mathrm{Mg}^{2+}, \mathrm{Cl}^{-}, \mathrm{SO}_{4}^{2-}, \mathrm{SiO}_{2}$, alkalinity and $\mathrm{pH}$ have been analysed for on a weekly basis. $\mathrm{K}^{+}$, $\mathrm{Na}^{+}, \mathrm{Ca}^{2+}$ and $\mathrm{Mg}^{2+}$ were analysed by atomic absorption spectrometry. $\mathrm{Cl}^{-}$and $\mathrm{SO}_{4}^{2-}$ were measured by 


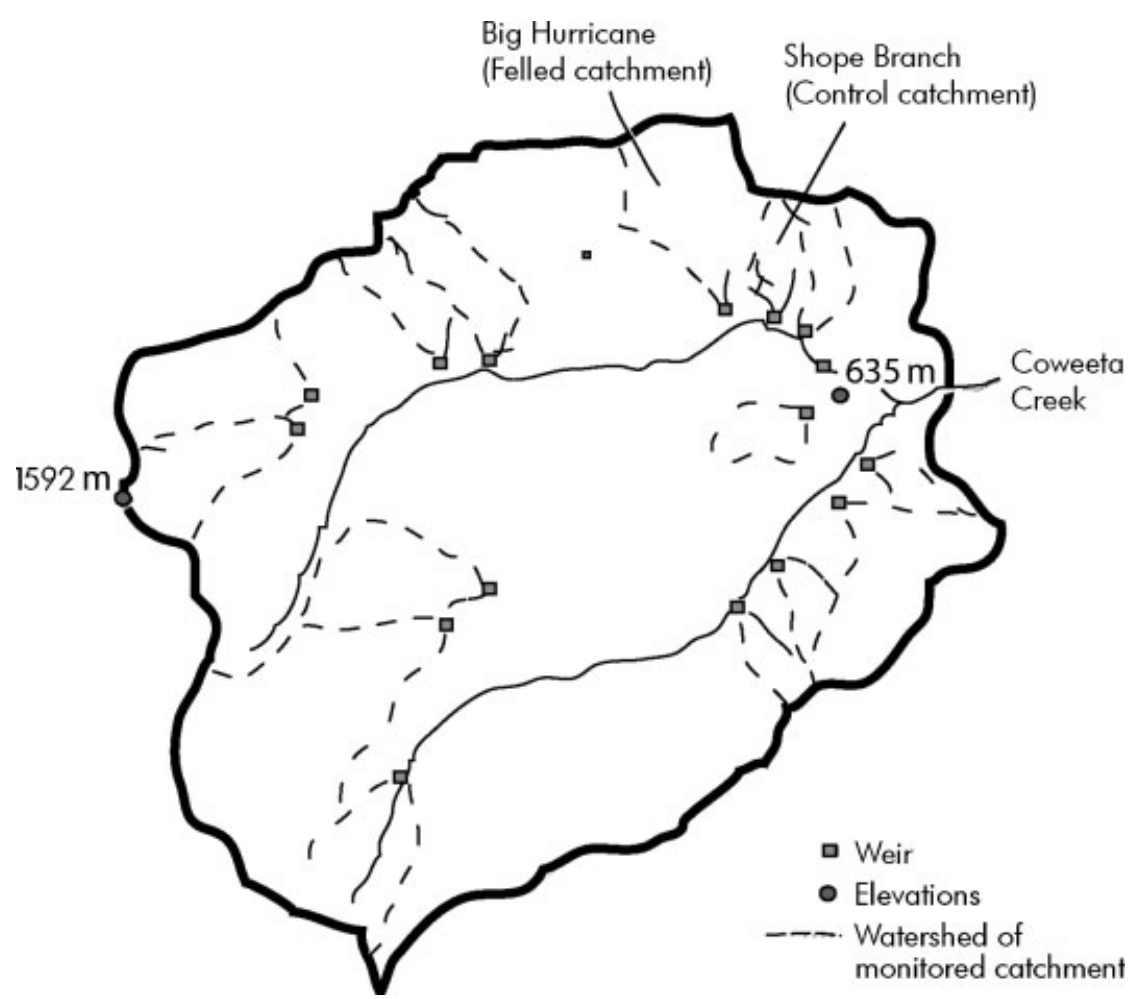

Figure 1. Location map of the Coweeta watershed. The map shows locality of the study catchments: catchment 2 (Shope Branch, control catchment) and catchment 7 (Big Hurricane, felled catchment). Scale: $1 \mathrm{~cm}=640 \mathrm{~m}$

micro-membrane suppressed ion chromatography. Automated colorimetry using segmented flow analysis was used to analyse $\mathrm{SiO}_{2}$ (Standard Methods for the Examination of Water and Wastewater, 1985a). Alkalinity was determined titrametrically and $\mathrm{pH}$ by electrode (Standard Methods for the Examination of Water and Wastewater, 1985b,c), both determined as soon after sample collection as practical to prevent degassing errors in the measurement.

Stream discharge is measured continuously on each watershed using $90^{\circ} \mathrm{V}$-notch weirs. Additionally, as meteorological conditions are monitored in the catchments, this means that results of time series analysis can be compared with detailed rainfall and temperature records.

\section{Inorganic carbon speciation}

The inorganic carbon species were calculated using the following equilibria for inorganic carbon species:

$$
\begin{aligned}
& {\left[\mathrm{CO}_{2}\right]_{\text {eqm }}=K_{\mathrm{H}} p \mathrm{CO}_{2}} \\
& \left(\mathrm{H}_{2} \mathrm{CO}_{3}\right)=0 \cdot 00049 k_{0} \mathrm{EpCO}_{2} \\
& \left(\mathrm{HCO}_{3}^{-}\right)=k_{1} \frac{\left(\mathrm{H}_{2} \mathrm{CO}_{3}\right)}{\left(\mathrm{H}^{+}\right)} \\
& \left(\mathrm{CO}_{3}^{2-}\right)=k_{2} \frac{\left(\mathrm{HCO}_{3}^{-}\right)}{\left(\mathrm{H}^{+}\right)} \\
& \left(\mathrm{CaHCO}_{3}^{+}\right)=k_{3}\left(\mathrm{Ca}^{2+}\right)\left(\mathrm{HCO}_{3}^{-}\right)
\end{aligned}
$$




$$
\begin{aligned}
& \left(\mathrm{CaCO}_{3}\right)=k_{4}\left(\mathrm{Ca}^{2+}\right)\left(\mathrm{CO}_{3}^{2-}\right) \\
& \left(\mathrm{CaOH}^{+}\right)=k_{5}\left(\mathrm{OH}^{-}\right)\left(\mathrm{Ca}^{2+}\right) \\
& \left(\mathrm{OH}^{-}\right)=\frac{k_{6}}{\left(\mathrm{H}^{+}\right)} \\
& K_{7}=\left(\mathrm{Ca}^{2+}\right)\left(\mathrm{CO}_{3}^{2-}\right)
\end{aligned}
$$

where parentheses indicate the activity of that component, square brackets indicate concentration of the component, $p \mathrm{CO}_{2}$ is the partial pressure of $\mathrm{CO}_{2}$ in the atmosphere, and the excess $\mathrm{CO}_{2}\left(\mathrm{EpCO}_{2}\right)$ is defined as the amount of dissolved $\mathrm{CO}_{2}$ in the water in comparison with that expected in equilibrium with the atmosphere:

$$
\mathrm{EpCO}_{2}=\frac{\left[\mathrm{CO}_{2}\right]_{\text {water }}}{\left[\mathrm{CO}_{2}\right]_{\text {eqm }}}
$$

Each of these equilibrium constants will vary with the water temperature

$$
\begin{aligned}
& \log _{10} k_{0}=0.01422(273+T)+\left(\frac{2299 \cdot 6}{273+T}\right)-13.417 \\
& \log _{10} k_{1}=14.8345-0.03279(273+T)-\left(\frac{3404 \cdot 71}{273+T}\right) \\
& \log _{10} k_{2}=0.022379(273+T)+\left(\frac{2902 \cdot 39}{273+T}\right)-6.498 \\
& \log _{10} k_{3}=2.95-0.0133(273+T) \\
& \log _{10} k_{4}=27.393-0.0561(273+T)-\left(\frac{4114}{273+T}\right) \\
& \log _{10} k_{5}=-1.4 \\
& \log _{10} k_{6}=0.017053(273+T)+\left(\frac{4471 \cdot 33}{273+T}\right)-6.0846 \\
& \log _{10} k_{7}=13.545-0.0401(273+T)-\left(\frac{3000}{273+T}\right) \\
& K_{\mathrm{H}}=\log _{10}\left\{0.034 \exp \left[\frac{-4.772}{0.001987}\left(\frac{1}{298}-\frac{1}{273+T}\right)\right]\right\}
\end{aligned}
$$

where $T\left({ }^{\circ} \mathrm{C}\right)$ is the stream temperature and thermodynamic information comes from Harned and Davis (1943: $K_{0}$ and $K_{1}$ ), Harned and Scholes (1941: $K_{2}$ ), Jacobsen and Langmuir (1974: $K_{3}$ and $K_{7}$ ), Reardon and Langmuir (1974: $K_{4}$ ), Gimblett and Monk (1954: $K_{5}$ ), Covington et al. (1977: $K_{6}$ ), and Stumm and Morgan (1996: $K_{\mathrm{H}}$ ).

$$
\left(\mathrm{Ca}^{2+}\right)=\gamma_{2} \frac{\left[\mathrm{Ca}^{2+}\right]}{40000}+\frac{k_{3}\left(\mathrm{HCO}_{3}^{-}\right)}{\gamma_{1}}+\frac{k_{4}\left(\mathrm{CO}_{3}^{2-}\right)}{\gamma_{1}}+\frac{k_{5}\left(\mathrm{OH}^{-}\right)}{\gamma_{1}}
$$

where square brackets refer to concentrations rather than activity, with adjustment made between the two being given by the Davis equation:

$$
\sqrt{I}=0.000564+\left(\mathrm{OH}^{-}\right)+\left(\mathrm{HCO}_{3}^{-}\right)+\left(\mathrm{H}^{+}\right)+\sqrt{2\left(\left(\mathrm{CO}_{3}^{2-}\right)+\frac{\left[\mathrm{Ca}^{2+}\right]}{40000}\right)}
$$


where

$$
\begin{aligned}
& \log _{10} \gamma_{1}=0 \cdot 3 \sqrt{I}-0 \cdot 5\left(\frac{\sqrt{I}}{1+\sqrt{I}}\right) \\
& \log _{10} \gamma_{2}=0 \cdot 3 \sqrt{I}-2\left(\frac{\sqrt{I}}{1+\sqrt{I}}\right)
\end{aligned}
$$

and where

$$
\mathrm{Alk}_{\mathrm{Gran}}=\left[\mathrm{HCO}_{3}^{-}\right]+2\left[\mathrm{CO}_{3}^{2-}\right]+\left[\mathrm{CaHCO}_{3}^{+}\right]+2\left[\mathrm{CaCO}_{3}\right]+\left[\mathrm{CaOH}^{+}\right]+\left[\mathrm{OH}^{-}\right]-\left[\mathrm{H}^{+}\right]
$$

Estimates of $\mathrm{EpCO}_{2}$ are corrected for changes in pressure with altitude using the methods of the Smithsonian Institute (1966):

$$
\begin{aligned}
& \frac{P_{a}}{P_{0}}=\left(\frac{288-0 \cdot 0065 a}{288}\right)^{5 \cdot 256} \\
& \mathrm{EpCO}_{2}=\frac{P_{a}}{P_{0}} \mathrm{EpCO}_{2 \text { (calculated) }}
\end{aligned}
$$

where $a(\mathrm{~m})$ is the catchment altitude, $P_{0}$ is the atmospheric pressure at sea level, and $P_{a}$ is the atmospheric pressure at altitude $a$.

This approach requires an estimate of $\mathrm{EpCO}_{2}$ and then can be solved iteratively by comparing the estimate of alkalinity from Equation (2) with that measured for the catchment. An initial estimate of $\mathrm{EpCO}_{2}$ can be calculated using the method of Neal et al. (1998):

$$
\mathrm{EpCO}_{2}=\frac{\left(0 \cdot 95 \mathrm{Alk}_{\mathrm{Gran}}+10^{6-\mathrm{pH}}+10^{6+\mathrm{pH}+\mathrm{p} K_{6}}\right) 10^{6-\mathrm{pH}}}{(6 \cdot 46-0 \cdot 0636 T)\left(1+2 \cdot 3810^{\mathrm{pH}-\mathrm{p} K_{2}}\right)}
$$

where $\mathrm{Alk}_{\mathrm{Gran}}\left(\mu \mathrm{eq} \mathrm{I}^{-1}\right.$ ) is the Gran alkalinity, and $T\left({ }^{\circ} \mathrm{C}\right)$ is water temperature.

Thus, free dissolved $\mathrm{CO}_{2}$ concentrations can be calculated from Equation (1) and is henceforward referred to as dissolved $\mathrm{CO}_{2}$. The DIC contents can be calculated using

$$
\mathrm{DIC}=\left[\mathrm{HCO}_{3}^{-}\right]+\left[\mathrm{H}_{2} \mathrm{CO}_{3}\right]+\left[\mathrm{CO}_{3}^{2-}\right]+\left[\mathrm{CaHCO}_{3}^{+}\right]+\left[\mathrm{CaCO}_{3}\right]
$$

Both dissolved $\mathrm{CO}_{2}$ and DIC are converted to units of milligrams per litre. Thus, inorganic carbon speciation and content can be calculated from a knowledge of the calcium, alkalinity, $\mathrm{pH}$ and temperature of the streamwater.

Stream temperature measurements are available for the felled catchment for the period 1976 to 1994 (Swift, 1982). Swift (1982) has shown that stream temperature is affected by the clear-felling of the catchment; so, for stream temperatures after the period of monitoring, a regression equation has been developed based upon the comparison of air and stream temperatures for the period 1986-94. The regression equation is

$$
T_{\mathrm{s}}=0.421 T_{\mathrm{a}}+6.89 \quad\left(n=419, r^{2}=0.88\right)
$$

where $T_{\mathrm{S}}\left({ }^{\circ} \mathrm{C}\right)$ is the stream temperature and $T_{\mathrm{a}}\left({ }^{\circ} \mathrm{C}\right)$ is the air temperature.

For the control catchment, no stream temperature data were available, but data were available for a comparable control catchment (catchment 10; (Figure 1) for the period 1976-94. As with the felled catchment, for the period post-1994 a regression equation was calculated on the basis of regression between air and stream temperatures for the period 1976-94.

The above calculations are for the dissolved $\mathrm{CO}_{2}$ and DIC content of the stream at the catchment outlet and not for the water leaving the soil and groundwater of the catchment. Once in the stream the dissolved 
$\mathrm{CO}_{2}$ can escape to the atmosphere or be altered by stream metabolism. Using the approach of Jones and Mulholland (1998a)

$$
p \mathrm{CO}_{2 \text { stream }}=p \mathrm{CO}_{2 \mathrm{gw}}-p \mathrm{CO}_{2 \text { evasion }}+p \mathrm{CO}_{2 \text { metabol }}
$$

where $p \mathrm{CO}_{2 s t r e a m}$ is the dissolved $\mathrm{CO}_{2}$ in the stream as calculated above, $p \mathrm{CO}_{2 \mathrm{gw}}$ is the dissolved $\mathrm{CO}_{2}$ from the soil-groundwater of the catchment, $p \mathrm{CO}_{2 \text { evasion }}$ is the dissolved $\mathrm{CO}_{2}$ lost to the atmosphere between groundwater emergence and the catchment monitoring point, and $p \mathrm{CO}_{2 \text { metabol }}$ is the dissolved $\mathrm{CO}_{2}$ from net in-stream metabolism between the emergence of the groundwater and the catchment monitoring point. For the purpose of this study it is $p \mathrm{CO}_{2 \mathrm{gw}}$ that is required, and so $p \mathrm{CO}_{2 \text { evasion }}$ and $p \mathrm{CO}_{2 \text { metabol }}$ must be estimated.

The evasion rate of $\mathrm{CO}_{2}$ from the streamwater can be estimated from the stagnant two-film model (Liss and Slater, 1974), although this assumes that stream surface can be considered as the same as a lake or sea surface:

$$
F=\frac{D_{\mathrm{CO}_{2}}}{z_{\mathrm{w}}}\left(\left[\mathrm{CO}_{2}\right]_{\mathrm{water}}-\left[\mathrm{CO}_{2}\right]_{\mathrm{air}}\right)
$$

where $F\left(\mathrm{mg} \mathrm{cm}^{2} \mathrm{~s}^{-1}\right)$ flux of $\mathrm{CO}_{2}$ (as carbon), $\mathrm{D}_{\mathrm{CO}_{2}}$ is the diffusion coefficient of $\mathrm{CO}_{2}$ in water $(2 \times$ $\left.10^{-5} \mathrm{~cm}^{2} \mathrm{~s}^{-1}\right), z_{\mathrm{w}}$ is the water film thickness $(40 \mu \mathrm{m})$, and $\left[\mathrm{CO}_{2}\right]_{\text {water/air }}$ is the $\mathrm{CO}_{2}$ concentration in air/water $\left(\mathrm{mg} \mathrm{cm}^{3}\right)$. The amount of $\mathrm{CO}_{2}$ lost during the passage from groundwater to monitoring point can then be calculated by knowledge of the residence time of the water in the stream and the stream surface area. The residence time for both catchments in this study is estimated from the flow in the catchment and dimensions of the stream; it is assumed that, on average, groundwater enters the stream at the midpoint of the channel length. The stream surface is estimated given knowledge of the flow, stream dimensions and the rating curve for the weirs in each of the study catchments.

The net in-stream metabolism is estimated using estimates of the respiration rates from Webster et al. (1999) and the average POC concentration measured for catchments 2 and 7 (Webster et al., 1988).

Once the dissolved $\mathrm{CO}_{2}$ content leaving the soil-groundwater system of the catchment has been calculated, the flux of dissolved $\mathrm{CO}_{2}$ and DIC is then calculated with reference to stream discharge measurements using 'method 5' (Walling and Webb, 1985). The annual cycles of $p \mathrm{CO}_{2 \mathrm{gw}}, p \mathrm{CO}_{2 \text { evasion }}$ and $p \mathrm{CO}_{2 \text { metabol }}$ are calculated using the method of seasonal indices of Worrall and Burt (1999). The method of seasonal indices uses monthly medians, calculated for the whole dataset, normalized against the median for the whole dataset to provide a measure of difference between each month and the median.

\section{Source of inorganic carbon}

The dissolved $\mathrm{CO}_{2}$ and DIC emerging into the stream is the result of mineral weathering and soil respiration. Mineral weathering consumes dissolved $\mathrm{CO}_{2}$ and generates DIC, whereas soil respiration generates dissolved $\mathrm{CO}_{2}$. The flow emerging into the stream comes from a range of flowpaths. The proportion of dissolved $\mathrm{CO}_{2}$ and DIC in the separate flowpaths of the catchment can be calculated by reference to the proportion of old and new water in the stream discharge, where it is assumed that old water comes via deep flowpaths interacting with the catchment mineralogy and that new water has not interacted with the regolith, either because it comes via shallower paths or has insufficient residence time to react. The proportion of old and new water in the stream discharge of the two study catchments was calculated using principal component analysis and is reported in Worrall et al. (2005).

\section{RESULTS}

The time series of those components important to the calculation of dissolved $\mathrm{CO}_{2}$ and DIC show that the catchments show very similar behaviour in terms of bicarbonate and $\mathrm{pH}$, but show differing levels of calcium 
(Figure 2). The iterative solution of the calculation for $\mathrm{EpCO}_{2}$ shows that there is a linear relationship between the final $\mathrm{EpCO}_{2}$ value and the initial estimate made from Equation (3):

$$
\mathrm{EpCO}_{2 \text { Calculated }}=0.719 \mathrm{EpCO}_{2 \mathrm{Estimated}}-0.04
$$

where $\mathrm{EpCO}_{2 \text { Calculated }}$ is the $\mathrm{EpCO}_{2}$ calculated by iterative solution and $\mathrm{EpCO}_{2 \mathrm{Estimated}}$ is the $\mathrm{EpCO}_{2}$ estimated from Equation (3).

The relationship between $\mathrm{EpCO}_{2}$ estimated from Equation (3) and $\mathrm{EpCO}_{2}$ calculated from the iterative solution of the complete speciation is slightly different between the two catchments, and so no general relationship can presently be suggested. However, the fact that such a strong linear relationship exists between the estimated and calculated values means that the iterative calculation need only be repeated a few times, sufficient for the relationship to be adequately specified, rather than repeated for all the samples from the catchment. A similar relationship between estimate and calculation has been found for other catchments in an entirely different context (Worrall and Burt, 2005) but was not found by Neal et al. (1998); it is possible that this is due to the method of measuring $\mathrm{pH}$ or alkalinity where degassing of collected samples may have occurred.

\section{Dissolved $\mathrm{CO}_{2}$}

The amount of $\mathrm{CO}_{2}$ produced by net in-stream metabolism $\left(p \mathrm{CO}_{2 \text { metabol }}\right)$ is minimal; in the control catchment the average carbon production is only $1.94 \mathrm{~kg} \mathrm{year}^{-1}$, (which is $0.005 \mathrm{~kg} \mathrm{year}^{-1}$ per metre of stream), ranging between 0.24 and $2.67 \mathrm{~kg} \mathrm{year}^{-1}$. In the felled catchment it is $1.75 \mathrm{~kg} \mathrm{year}^{-1}$, which is $0.001 \mathrm{~kg} \mathrm{year}^{-1}$ per metre of stream, ranging between 0.37 and $5.39 \mathrm{~kg} \mathrm{year}^{-1}$. The critical factor is the residence time in the catchment, and an examination of the time series of dissolved $\mathrm{CO}_{2}$ concentration added to the catchment outlet by net in-stream metabolism shows that it peaks at times of lowest flow, i.e. in the late summer months (Figure 3). Despite the differing values of production, the nature of the productivity response is identical between the catchments, with a slightly greater amplitude to the annual cycle in the control catchment reflecting its greater seasonal variation in flow (Figure 4).

The average amount of $\mathrm{CO}_{2}$ (as carbon) lost to evasion in the control catchment is $239 \mathrm{~kg}^{-1}$ year $^{-1}$, ranging from 110 to $1026 \mathrm{~kg} \mathrm{year}^{-1}$, or $0.54 \mathrm{~kg} \mathrm{year}^{-1}$ per metre of stream, whereas in the felled catchment the average is $932 \mathrm{~kg} \mathrm{year}^{-1}\left(437-3502 \mathrm{~kg} \mathrm{year}^{-1}\right)$ or $0.9 \mathrm{~kg} \mathrm{year}^{-1}$ per metre of stream. The higher value of evasion from the felled catchment reflects the longer residence time in this larger catchment. Apart from differences in general levels of evasion, the nature of the evasion appears common between the two catchments (Figure 4) and once again reflects the annual cycle in flow and the residence time in the stream.

The average dissolved $\mathrm{CO}_{2}$ (as carbon) exported in the streams from the control catchment is $3.72 \mathrm{t} \mathrm{km}^{-2}$ year ${ }^{-1}$, ranging between 2.33 and $13.94 \mathrm{t} \mathrm{km}^{-2} \mathrm{year}^{-1}$. For the felled catchment the average dissolved $\mathrm{CO}_{2}$ exported in the streams from the felled catchment is $3.48 \mathrm{t} \mathrm{km}^{-2}$ year $^{-1}$, ranging between 1.68 and $14.17 \mathrm{t} \mathrm{km}^{-2}$ year $^{-1}$ (Figure 3). The areal production of dissolved $\mathrm{CO}_{2}$ for the two catchments is almost identical, and a visual comparison of the time series of the annual flux between the two catchments shows no difference between the time series of each catchment, save for a phase shift apparent in the large export in years 1997-98 (Figure 3). The lack of difference between the two catchments suggests that the clear-felling of the felled catchment had little or no effect on the processes controlling inorganic carbon release. The lack of effect of clear-felling on the flowpaths within the felled catchment has been demonstrated by Worrall et al. (2005). The combination of flowpaths is one of the controls on flushing of inorganic carbon, but other controls include the turnover rate of organic matter in the soil profile and the weathering rate of soil minerals and underlying strata. The equivalence of the export from these two catchments during the early years of the observed time series suggests that neither weathering rate nor the turnover rate of organic matter are altered by clear-felling. Jones et al. (2003) have suggested that long-term trends (since 1973) in $\mathrm{CO}_{2}$ saturation of US rivers are downwards. Most of the evidence from their study comes from large watersheds, but their conclusion is not supported here for these two headwater catchments. Jones et al. (2003) ascribe the decline 

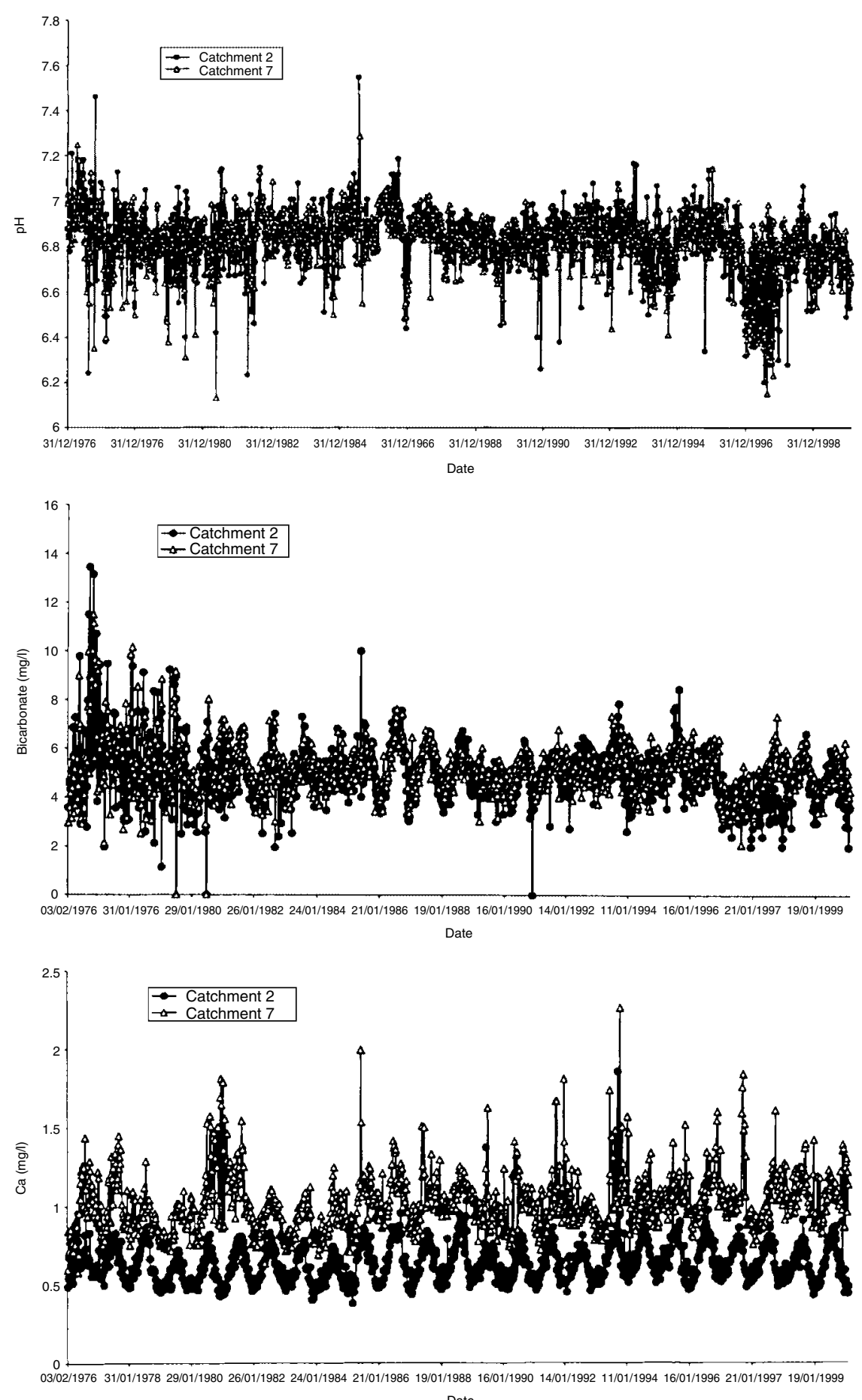

Date

Figure 2. Time series of $\mathrm{pH}$, bicarbonate and $\mathrm{Ca}^{2+}$ from the study catchments over the study period 

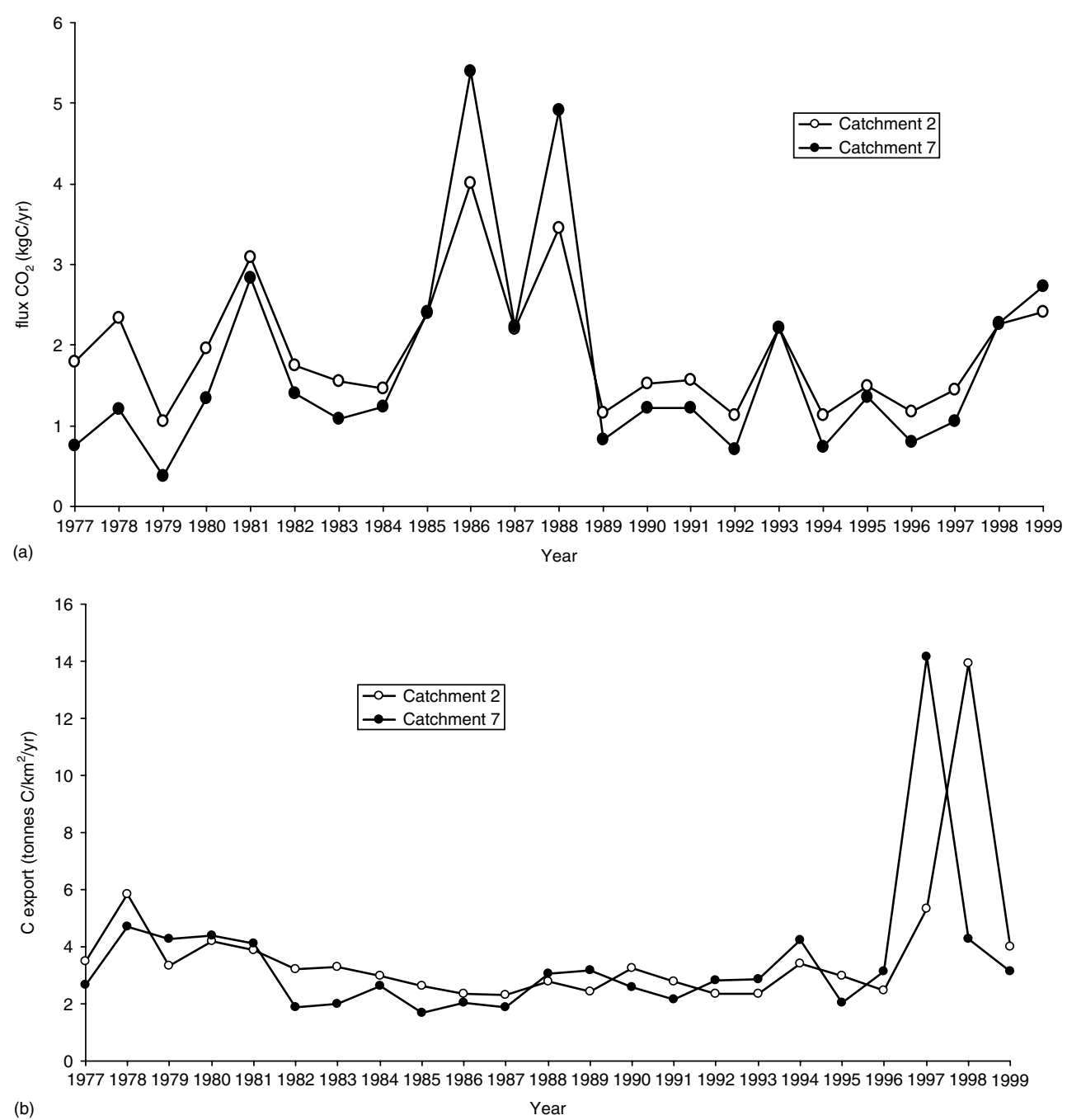

Figure 3. (a) The annual production of $\mathrm{CO}_{2}$ by in-stream metabolism from the study catchments. (b) Annual flux of dissolved $\mathrm{CO}_{2}$ from the study catchments across the period of the study

to diminishing terrestrial $\mathrm{CO}_{2}$ production; and the Jones et al., 2003 study suggests that soil $\mathrm{CO}_{2}$ production is robust against changes in land use.

The large export of dissolved $\mathrm{CO}_{2}$ during the period 1997-98 can be associated with an acidification event in the whole Coweeta basin with $\mathrm{pH}$ decreasing from approximately 6.8 to 6.4 (Figure 2). The consequences of the acidification event appear earlier in the felled catchment than in the control catchment. A phase difference between the annual cycles in stream chemistry and the proportion of old and new water in the streamwater of these catchments has previously been noted and has been ascribed to differences in depth of interaction of percolating water between the two catchments (Worrall et al., 2005). However, no explanation in any study has been provided for this event.

The annual cycle of the dissolved $\mathrm{CO}_{2}$ concentration emerging from the catchment shows that it is greatest during the period of lowest flow (Figure 4). The fact that the dissolved $\mathrm{CO}_{2}$ concentration is highest at the time of lowest flow reflects the fact that the greater proportion of the dissolved $\mathrm{CO}_{2}$ is carried in the old 


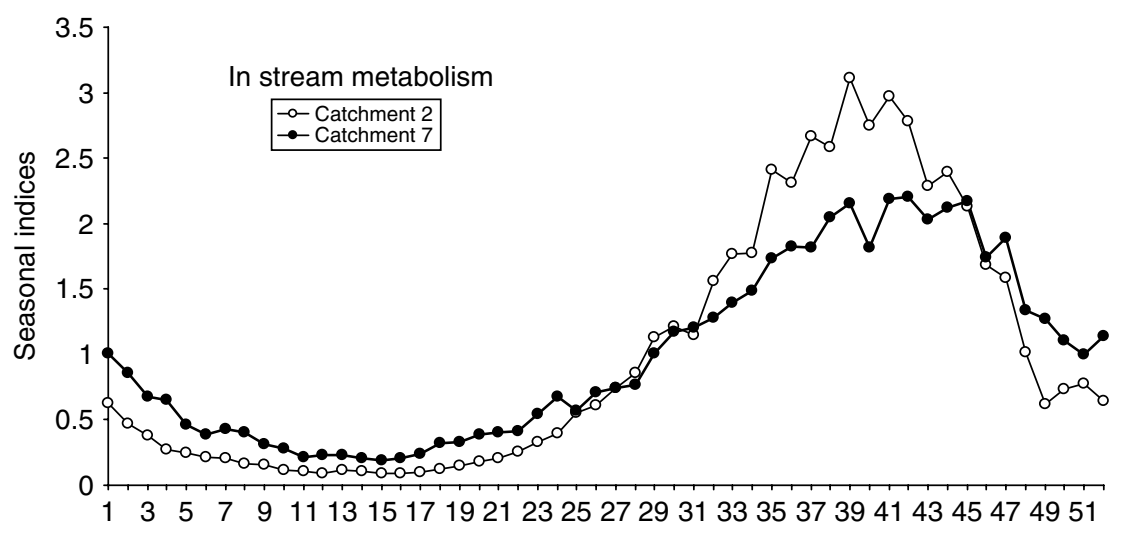

(a) Week
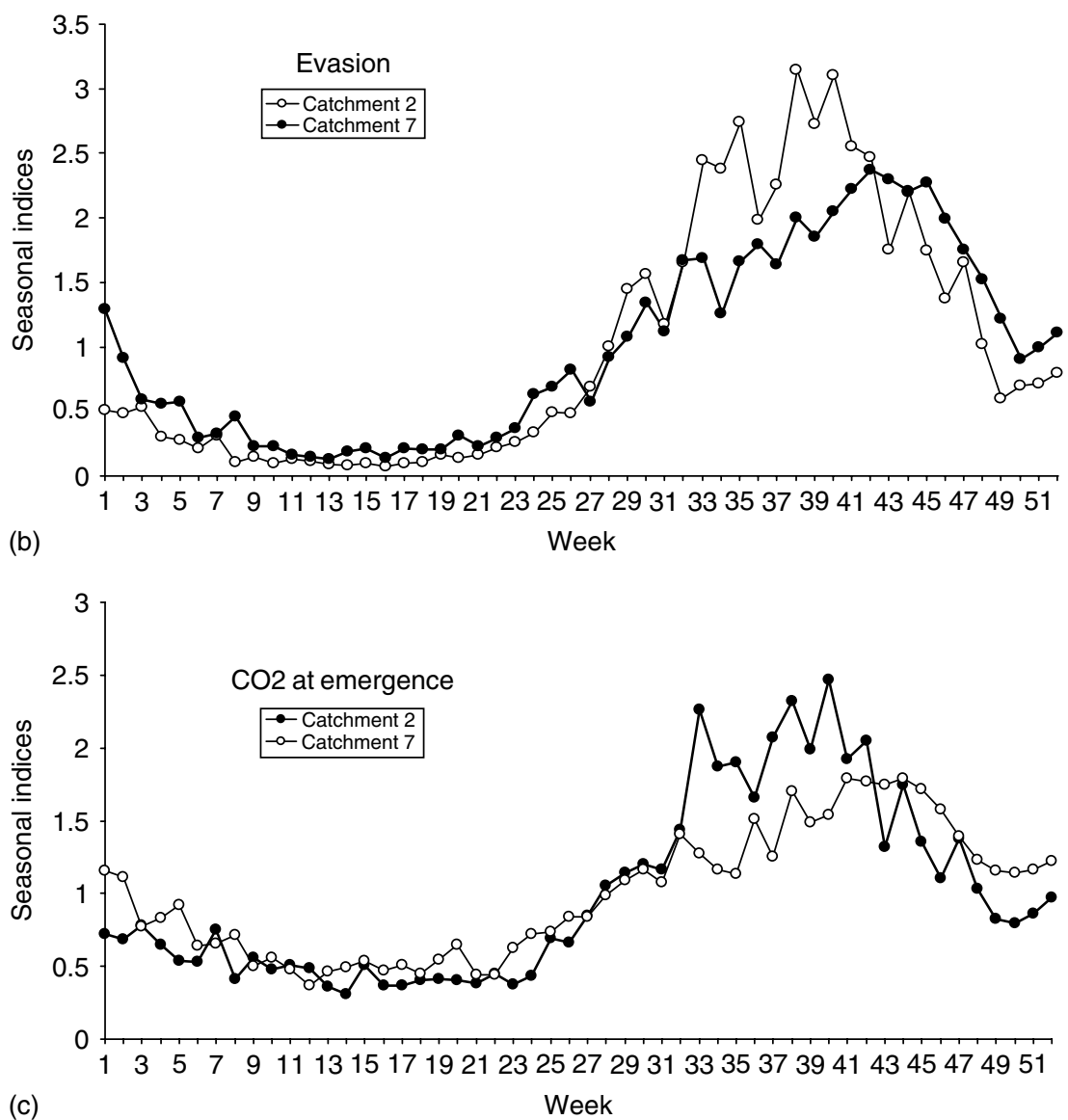

Figure 4. Seasonal indices for (a) the net in-stream metabolism from the study catchments, (b) seasonal indices for the evasion of $\mathrm{CO}_{2}$ from the streams of the study catchments, and (c) seasonal indices for the flux of dissolved $\mathrm{CO}_{2}$ at emergence for the streams of the study catchments

water. The analysis of the proportion of dissolved $\mathrm{CO}_{2}$ is limited to years prior to the acidification event, as the event alters the basis upon which the analysis of flow separation is performed. 
$D I C$

The flux of DIC from the catchments is close to that of the dissolved $\mathrm{CO}_{2}$ for both catchments: $5.15 \mathrm{t} \mathrm{km}^{-2}$ (of carbon) for the control catchment and $3.31 \mathrm{t} \mathrm{km}^{-2}$ (of carbon) for the felled catchment (Figure 5). The amounts of DIC between the catchments show the same phase shift during the acidification event as with the dissolved $\mathrm{CO}_{2}$, and again the flux is dominated by flux of the old water from the catchment. Also, the low flux values from both catchments between 1985 and 1988 are due to the record drought and very low discharges during this period.

\section{Comparison with organic carbon fluvial flux}

Tate and Meyer (1983; Meyer and Tate, 1983) report values of DOC flux for Coweeta catchments that range from 0.69 to $2.08 \mathrm{t} \mathrm{km}^{-2} \mathrm{year}^{-1}$ (of carbon); these figures include values for disturbed and control catchments at Coweeta, but not for either of the catchments used in this study (Table I). Qualls et al. (2002) examined the production of soluble organic nutrients from the control catchment and found that DOC flux for the period 1986-87 (a period of severe drought) was $0.41 \mathrm{t} \mathrm{km}^{-2}$ year $^{-1}$ (of carbon). From the review of Hope et al. (1994), the range of DOC flux values (as carbon) for temperate forests in the USA was $0.34 \mathrm{t} \mathrm{km}^{-2}$ year (Mack Creek, Oregon; Moeller et al., 1979) to $5.45 \mathrm{t} \mathrm{km}^{-2}$ year $^{-1}$ (Roaring Creek, Mass achusetts; McDowell and Fisher, 1976). A more recent compilation of DOC data from forests (Buffam et al., 2001) gave no higher or lower values than those reported by Hope et al. (1994). The relatively small amount of DOC that is exported from the catchments at Coweeta can be ascribed to adsorption of DOC in soil horizons; Qualls et al. (2002) show that there is $99.3 \%$ retention of DOC within the soil.

With regard to POC, far fewer values have been reported in the literature. Values for the Coweeta catchments have been reported by Webster et al. (1999); for the control catchment the carbon value for 1983-84 is $2.97 \mathrm{t} \mathrm{km}^{-2}$ year $^{-1}$ and $4.36 \mathrm{t} \mathrm{km}^{-2}$ year ${ }^{-1}$ for the felled catchment. From the review of Hope et al. (1994), the minimum reported carbon value is $0.07 \mathrm{t} \mathrm{km}^{-2}$ year-1 (Bear Brook, New Hampshire, Fisher and Likens, 1973) to $1.16 \mathrm{t} \mathrm{km}^{-2}$ year $^{-1}$ (Susquehanna River; Flemer and Biggs, 1971).

The number of values for inorganic carbon flux and dissolved $\mathrm{CO}_{2}$ for headwater forested catchments reported in the literature are limited. Hope et al. (1994) report only one study of DIC flux from a forested catchment in the conterminous USA, $0.76 \mathrm{t} \mathrm{km}^{-2}$ year $^{-1}$ (Likens et al., 1977).

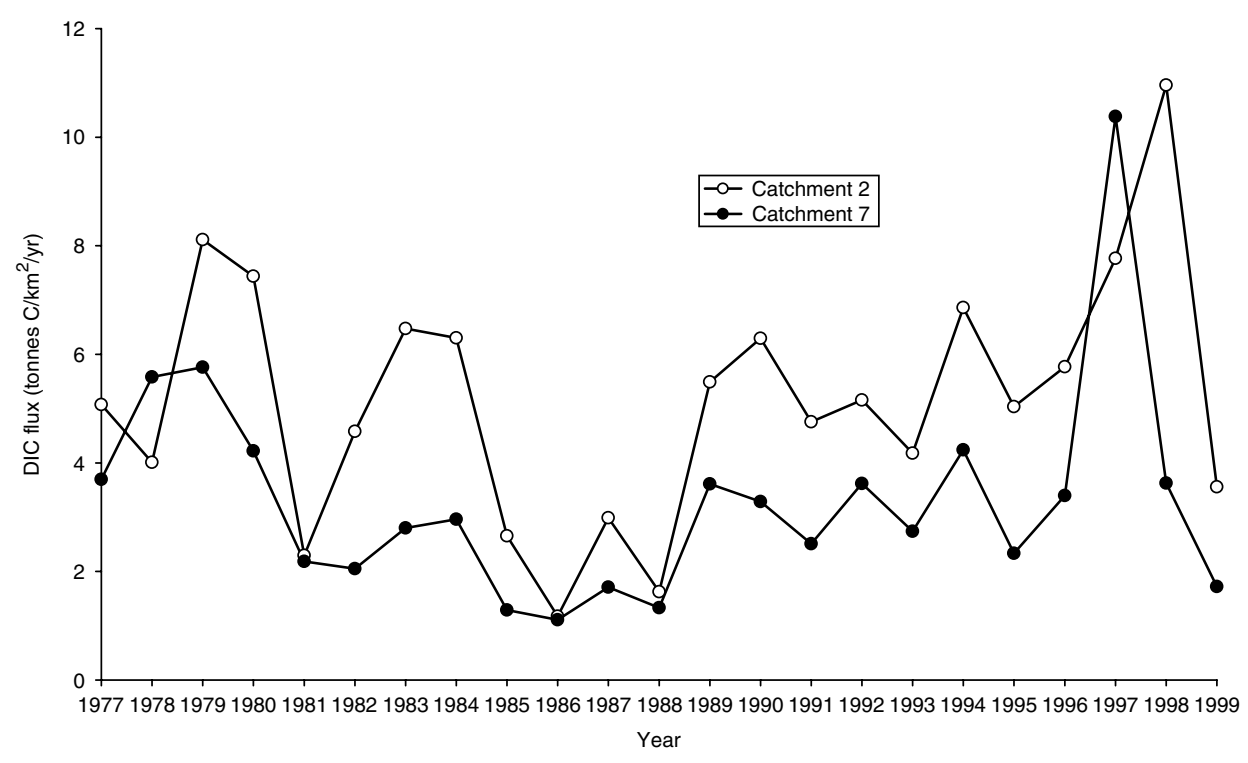

Figure 5. Annual flux of DIC from the study catchments across the period of the study 
Table I. Total fluvial carbon flux from the study catchments

\begin{tabular}{|c|c|c|c|c|c|}
\hline & \multicolumn{4}{|c|}{ Carbon flux ( $\mathrm{tm}^{-2}$ year $\left.^{-1}\right)$} & \multirow[t]{2}{*}{ Reference } \\
\hline & Control catchment & Range & Felled catchment & Range & \\
\hline Dissolved $\mathrm{CO}_{2}$ & $3 \cdot 72$ & $2 \cdot 33-13 \cdot 94$ & $3 \cdot 48$ & $1 \cdot 68-14 \cdot 17$ & This study \\
\hline DIC & $4 \cdot 25$ & & $2 \cdot 89$ & & This study \\
\hline DOC & $0 \cdot 41$ & $0 \cdot 69-2 \cdot 08$ & $0 \cdot 41$ & $0 \cdot 69-2 \cdot 08$ & $\begin{array}{l}\text { Qualls et al. (2000), Tate } \\
\text { and Meyer (1985), } \\
\text { Webster et al. (1999) }\end{array}$ \\
\hline POC & $2 \cdot 97$ & & $4 \cdot 36$ & & \\
\hline Dissolved $\mathrm{CH}_{4}$ & $0 \cdot 26$ & $0 \cdot 12-0 \cdot 40$ & $0 \cdot 26$ & $0 \cdot 12-0 \cdot 40$ & $\begin{array}{l}\text { Jones and Mulholland } \\
\quad(1998 \mathrm{c})\end{array}$ \\
\hline Total & $11 \cdot 6$ & $10 \cdot 4-23 \cdot 6$ & $11 \cdot 4$ & $9.7-23.9$ & \\
\hline
\end{tabular}

To our knowledge, there is only one study of dissolved $\mathrm{CH}_{4}$ flux from forested catchments (Jones and Mulholland, 1998c), where dissolved $\mathrm{CH}_{4}$ concentrations on emergence into the stream were found to be between 0.16 and $0.55 \mathrm{mg} \mathrm{l}^{-1}$ (as carbo). If these values are taken as representative of the catchments in this study, and they are for Appalachian catchments, then the range in dissolved $\mathrm{CH}_{4}$ flux would between $0 \cdot 12$ and $0.40 \mathrm{t} \mathrm{km}^{-2}$ year $^{-1}$ (as carbon).

Given the fluxes calculated in this study, and in combination with literature values, it is possible to compile a total fluvial carbon flux for the study catchments (Table I). The total fluvial carbon fluxes from the two catchments are not significantly different. Given the ranges reported above and in the literature, the range of total fluvial carbon flux for the two catchments is $9.7-23.9 \mathrm{t} \mathrm{km}^{-2}$ year ${ }^{-1}$.

\section{DISCUSSION}

The methodology presented in this study makes the assumption that the dominant divalent cation is $\mathrm{Ca}^{2+}$ and that the inorganic carbon speciation can be adequately accounted for based on $\mathrm{Ca}^{2+}$ alone, without reference to $\mathrm{Mg}^{2+}$ for example. For the study catchments, the concentration of $\mathrm{Mg}^{2+}$ is typically $50 \%$ of that of $\mathrm{Ca}^{2+}$, i.e. $\mathrm{Ca}^{2+}$ is the dominant cation but concentrations of $\mathrm{Mg}^{2+}$ are still significant. However, the calculation of dissolved $\mathrm{CO}_{2}$ is most sensitive to $\mathrm{pH}$, temperature and alkalinity, i.e. the nature of the calculation would be little affected by an allowance for the concentration of $\mathrm{Mg}^{2+}$. Furthermore, previous studies of dissolved $\mathrm{CO}_{2}$ from forested catchments have based their calculations of dissolved $\mathrm{CO}_{2}$ content on alkalinity alone.

The concentration of dissolved $\mathrm{CO}_{2}$ in emerging groundwater is controlled by two processes: soil respiration and weathering. Soil respiration generates $\mathrm{CO}_{2}$ in the soil atmosphere; this $\mathrm{CO}_{2}$ can diffuse out of the soil profile into the atmosphere, but equally it can be dissolved into soil water. Water moving rapidly through the profile will not have time to equilibrate with the soil atmosphere and will, therefore, contribute very little to the dissolved $\mathrm{CO}_{2}$ content of catchment streams. Water with a longer residence time can equilibrate with the soil atmosphere and would thus be expected to contribute to the majority of the dissolved $\mathrm{CO}_{2}$ in the stream. Dissolved $\mathrm{CO}_{2}$ in groundwater will react with mineral components in the soil profile and regolith; weathering reactions will consume dissolved $\mathrm{CO}_{2}$. Therefore, if several details are known, then it should be possible to extrapolate from the dissolved $\mathrm{CO}_{2}$ content of the streamwater at emergence to the dissolved $\mathrm{CO}_{2}$ concentration in groundwater. To perform this extrapolation, two factors are required. First, if the proportion of old and new water contributing to the stream is known, then the fraction of dissolved $\mathrm{CO}_{2}$ at emergence coming from groundwater can be calculated. Second, if the weathering reactions are known, and the amount of weathering can be discerned from other chemical components measured in the stream, then the amount of dissolved $\mathrm{CO}_{2}$ consumed by weathering reactions can be calculated. 
If it is assumed that old water in the catchment is in equilibrium with the soil atmosphere, then once the $\mathrm{CO}_{2}$ concentration of groundwater is calculated the $\mathrm{CO}_{2}$ content of the soil atmosphere can easily be estimated by applying Henry's law. The $\mathrm{CO}_{2}$ concentration of the soil atmosphere can be related to the soil flux of $\mathrm{CO}_{2}$ by application of the diffusion equation (Jones and Mulholland, 1998a). Such a series of calculations relating dissolved $\mathrm{CO}_{2}$ at stream emergence to soil respiration are not presently justified within the present dataset; however, the explanation of the link between stream dissolved $\mathrm{CO}_{2}$ and soil $\mathrm{CO}_{2}$ flux shows that the time series of dissolved $\mathrm{CO}_{2}$ presented here are an expression of the soil $\mathrm{CO}_{2}$ flux. This means that dramatic changes in dissolved $\mathrm{CO}_{2}$ would also mean dramatic changes in soil respiration, and there are no such observed changes in the dissolved $\mathrm{CO}_{2}$ record. Johnson et al. (2002) found that clear-felling at Coweeta had no long-term change in soil carbon reserves, and that this was true for forest sites throughout the southeastern USA. However, Johnson and Curtis (2001) used meta-analysis to show that a slight positive effect on soil carbon reserves might be expected following tree harvesting. This suggests that soil $\mathrm{CO}_{2}$ might well be little altered by forest management.

The study clearly shows that dissolved $\mathrm{CO}_{2}$ and DIC dominate the fluvial flux of carbon from these forested catchments. If the area of forest in the USA between 1980 and 1990 was estimated to be $2.47 \times 10^{8}$ ha (Pacala et al., 2001), and if the values of fluvial carbon exports for the Coweeta catchments are taken as an order of magnitude correct estimate for all forested catchments, then the annual fluvial export of carbon from forests would be $2.8 \times 10^{7}$ t. Of this, $29 \%$ is as dissolved $\mathrm{CO}_{2}$, which will equilibrate with the atmosphere and release large amounts of carbon back into the atmosphere. Moreover, in-stream metabolism could lead to release of carbon to the atmosphere from the POC, DOC and DIC components. Meybeck (1993) estimated that the flux of DOC and DIC from the world's rivers was of the order of $24 \times 10^{7} \mathrm{t}^{-1} \mathrm{r}^{-1}$ (as carbon). However, Cole et al. (1994), in a survey of 1835 lakes across the globe, have shown that, on average, lakes were supersaturated with respect to the atmosphere by a factor of 3 ; assuming this value is correct, then degassing of $\mathrm{CO}_{2}$ from lakes would represent an additional $14 \times 10^{7} \mathrm{t}$ of carbon to the atmosphere per year, i.e. carbon flux estimates appear to underestimate the importance of dissolved $\mathrm{CO}_{2}$. It is unclear to what extent the fluvial flux of carbon, an example of which has been calculated by this study, has been accounted for in forest carbon budgets.

\section{CONCLUSIONS}

This study presents a method for calculating the total inorganic carbon flux from a catchment. The application to two forested catchments shows that:

1. Fluvial carbon release in catchments where DOC is effectively sequested by adsorption in the soil profile is dominated by inorganic carbon flux, both dissolved $\mathrm{CO}_{2}$ and DIC. The total inorganic carbon flux represents $69 \%$ of the total fluvial flux.

2. Total fluvial carbon flux from the clear-felled catchment is $11.6 \mathrm{t} \mathrm{km}^{-2}$ year ${ }^{-1}$ and for the control catchment it is $11.4 \mathrm{t} \mathrm{km}^{-2}$ year $^{-1}$.

3. Areal production rates of both dissolved $\mathrm{CO}_{2}$ and DIC are similar between the two catchments, even during and immediately after the period of clear-felling.

4. DIC and dissolved $\mathrm{CO}_{2}$ are dominantly released in the old water portion of the discharge and concentrations peak in the early autumn, when flows in the study catchments are at their lowest.

5. Flux of total inorganic carbon (dissolved $\mathrm{CO}_{2}+$ DIC) rises dramatically in response to a catchment-wide acidification event.

\section{REFERENCES}

Buffam I, Galloway JN, Blum LK, McGlathery KJ. 2001. A stormflow/baseflow comparison of dissolved organic matter concentrations and bioavailability in an Appalachian stream. Biogeochemistry 53: 269-306. 
Cole JJ, Caraco NF, Kling GW, Kratz TK. 1994. Carbon dioxide supersaturation in the surface water of lakes. Science 265: $1568-1570$.

Covington AK, Ferra MA, Robinson RA. 1977. Ionic product and enthalpy of ionisation of water from electromotive force measurements. Journal of the Chemical Society, Faraday Transactions 1: 1721-1730.

Day Jr FP, Phillips DL, Monk CD. 1988. Forest communities and patterns. In Forest Hydrology and Ecology at Coweeta, Swank WT, Crossley Jr DA (eds) Ecological Studies, vol. 66. Springer-Verlag: New York; 141-150.

Fisher SG, Likens GE. 1973. Energy flow in Bear Brook, New Hampshire; an integrative approach to stream ecosystem metabolism. Ecological Monograph 43: 421-439.

Flemer DA, Biggs RB. 1971. Particulate carbon : nitrogen relations in northern Chesapeake Bay. Journal of the Fisheries Research Board of Canada 28: 911-918.

Gimblett FGR, Monk CB. 1954. EMF studies of electrolytic dissociation, part 7. Some alkali and alkaline earth metal hydroxides in water. Transactions of the Faraday Society 76: 964-972.

Goodale CL, Apps MJ, Birdsey RA, Field CB, Heath LS, Houghton RA, Jenkins JC, Kohlmaier GH, Kurz W, Liu S, Nabuurs G-J, Nilsson S, Shvidenko AZ. 2002. Forest carbon sinks in the Northern Hemisphere. Ecological Applications 12: 891-899.

Harned HS, Davis Jr R. 1943. The ionisation constant of carbonic acid in water and the solubility of carbon dioxide in water and aqueous salt solutions from $0-50^{\circ}$ C. Journal of the American Chemical Society 65: 2030-2037.

Harned HS, Scholes Sr. 1941. The ionisation constant of $\mathrm{HCO}_{3}$ from 0-50 ${ }^{\circ} \mathrm{C}$. Journal of the American Chemical Society 63: $1706-1709$.

Hatcher Jr RD. 1988. Bedrock geology and regional geologic setting of Coweeta Hydrologic Laboratory in the eastern Blue Ridge. in Forest Hydrology and Ecology at Coweeta, Swank WT, Crossley Jr DA (eds). Ecological Studies, vol. 66. Springer-Verlag: New York; 81-92.

Hope D, Billet MF, Cresser MS. 1994. A review of the export of carbon in river water: fluxes and processes. Environmental Pollution 84: $301-324$.

Jacobsen RL, Langmuir D. 1974. Dissociation constants of calcite and $\mathrm{CaHCO}_{3}{ }^{+}$from $0-50{ }^{\circ} \mathrm{C}$. Geochimica et Cosmochimica Acta 38: $301-318$.

Johnson DW, Curtis PS. 2001. Effects of forest management on soil carbon and nutrient storage: meta-analysis. Forest Ecology and Management 140: 227-238.

Johnson DW, Knoepp JD, Swank WT, Shan J, Morris LA, Van Lear DH, Kapeluck PR. 2002. Effects of forest management on soil carbon: results of some long-term resampling studies. Environmental Pollution 116: S201-S208.

Jones JB, Mulholland PJ. 1998a. Carbon dioxide variation in a hardwood forest stream: an integrative measure of whole catchment soil respiration. Ecosystems 1: 183-196.

Jones JB, Mulholland PJ. 1998b. Influence of drainage basin topography and elevation on carbon dioxide and methane supersaturation of stream water. Biogeochemistry 40: 57-72.

Jones JB, Mulholland PJ. 1998c. Methane input and evasion in a hardwood forest stream: effects of subsurface flow from shallow and deep pathways. Limnology and Oceanography 43: 1243-1250.

Jones JB, Stanley EH, Mulholland PJ. 2003. Long-term decline in carbon dioxide supersaturation in rivers across the contiguous United States. Geophysical Research Letters 30: 1495.

Likens GE, Bormann FH, Pierce RS, Eaton JS, Johnson NM. 1977. Biogeochemistry of a Forested Ecosystem. Springer-Verlag: New York.

Liss PS, Slater PG. 1974. Flux of gases across the air-sea interface. Nature 247: 181-184.

McDowell WH, Fisher SG. 1976. Autumnal processing of dissolved organic matter in a small woodland stream ecosystem. Ecology 57: $561-569$.

Meybeck M. 1993. Riverine transport of atmospheric carbon-sources, global typology and budget. Water, Soil and Air Pollution 70: 443-463.

Meyer JL, Tate CM. 1983. The effects of watershed disturbance of dissolved organic carbon dynamics of a stream. Ecology 64: 33-44.

Moeller JR, Minshall GW, Cummins KW, Petersen RC, Cushing CE, Sedell JR, Larson RA, Vannote RL. 1979. Transport of dissolved organic carbon in streams of differing physiographic characteristics. Organic Geochemistry 1: 139-150.

Neal C, House WA, Down K. 1998. An assessment of excess carbon dioxide partial pressure in natural waters based on pH and alkalinity measurements. Science of the Total Environment 210-211: 173-185.

Pacala SW, Hurtt GC, Baker D, Peylin P, Houghton RA, Birdsey RA, Heath L, Sundquist ET, Stallard RF, Clais P, Moorcroft P, Caspersen JP, Shevliakova E, Moore B, Kohlmaler G, Holland E, Gloor M, Harmon ME, Fan S-M, Sarmiento JL, Goodale CL, Schimel D, Field CB. 2001. Consistent land- and atmosphere-based US carbon sink estimates. Science 292: 2316-2320.

Qualls RG, Haines BL, Swank WT, Tyler SW. 2000. Soluble organic and inorganic nutrient fluxes in clearcut and mature deciduous forests. Soil Science Society of America Journal 61: 1068-1077.

Qualls RG, Haines BL, Swank WT, Tyler SW. 2002. Retention of soluble organic nutrients by a forested ecosystem. Biogeochemistry 61: $133-171$.

Reardon EJ, Langmuir D. 1974. Thermodynamic properties of the ion pairs $\mathrm{MgCO}_{3}$ and $\mathrm{CaCO}_{3}$ from 10 to $50{ }^{\circ} \mathrm{C}$. American Journal of Science 274: 599-612.

Smithsonian Institute. 1966. Smithsonian Miscellaneous Collections, 114, 6th edition. Smithsonian Institute Press: Washington.

Standard Methods for the Examination of Water and Wastewater. 1985a. Determination of silicate by automated wet chemistry, Method 425 E, 16th edition.

Standard Methods for the Examination of Water and Wastewater. 1985b. Determination of alkalinity, Method 403, 16th edition.

Standard Methods for the Examination of Water and Wastewater. 1985c. Determination of pH, Method 423, 16th edition.

Stumm W, Morgan JJ. 1995. Aquatic Chemistry-Chemical Equilibria and Rates in Natural Waters, 3rd edition. Wiley Interscience: New York.

Swank WT, Waide JB. 1988. Characterisation of baseline precipitation and stream chemistry and nutrient budgets for control watersheds. In Forest Hydrology and Ecology at Coweeta, Swank WT, Crossley Jr DA (eds). Ecological Studies, vol. 66. Springer-Verlag: New York; $57-79$. 
Swank WT, Vose JM, Elliot KJ. 2001. Long-term hydrologic and water quality responses following commercial clearcutting of mixed hardwoods on a southern Appalachian catchment. Forest Ecology and Management 143: 163-178.

Swift LW. 1982. Duration of stream temperature increases following forest cutting in the southern Appalachian mountains. In International Symposium on Hydrometeorology, American Water Resource Association; 273-275.

Swift LW, Cunningham GB, Douglass JE. 1988. Climatology and hydrology. In Forest Hydrology and Ecology at Coweeta, Swank WT, Crossley Jr DA (eds). Ecological Studies, vol. 66. Springer-Verlag: New York; 35-56.

Tate CM, Meyer JL. 1983. The influence of hydrologic conditions and successional state on dissolved organic carbon export from forested watersheds. Ecology 64: 25-32.

Walling DE, Webb BW. 1985. Estimating the discharge of contaminants to coastal waters by rivers: some cautionary comments. Marine Pollution Bulletin 16: 488-492.

Webster JR, Benfield EF, Golladay SW, Kazmierczak Jr RF, Perry WB, Peters GT. 1988. Effects of watershed disturbance on stream seston characteristics. In Forest Hydrology and Ecology at Coweeta, Swank WT, Crossley Jr DA (eds). Ecological Studies, vol. 66. Springer-Verlag: New York; 279-296.

Webster JR, Benfield EF, Ehrman TP, Schaeffer MA, Tank JL, Hutchins JJ, D’Angelo DJ. 1999. What happens to allochthonous material that falls into streams? A synthesis of new and published information from Coweeta. Freshwater Biology 41: 687-705.

Worrall F, Burt TP. 1999. A univariate model of river water nitrate time series. Journal of Hydrology 214: 74-90.

Worrall F, Burt TP. 2005. Reconstructing long-term records of dissolved $\mathrm{CO}_{2}$. Hydrological Processes 19: in press.

Worrall F, Swank WT, Burt TP. Long-term controls on hydrological pathways: evidence from changes in stream chemistry of a forested catchment. Journal of Hydrology in press. 